\title{
The mountain-lowland debate: Deforestation and sediment transport in the upper Ganga catchment
}

\author{
R.J. Wasson ${ }^{\mathrm{a}, *}$, N. Juyal ${ }^{\mathrm{b}}$, M. Jaiswal ${ }^{\mathrm{b}}$, M. McCulloch ${ }^{\mathrm{d}}$, M.M. Sarin ${ }^{\mathrm{b}}$, \\ V Jain ${ }^{\mathrm{e}}$, P. Srivastava ${ }^{\mathrm{c}}$, A.K. Singhvi ${ }^{\mathrm{b}}$ \\ ${ }^{a}$ Charles Darwin University, Darwin, NT 0909, Australia \\ ${ }^{\mathrm{b}}$ Physical Research Laboratory, Ahmedabad 380 000, India \\ ${ }^{\mathrm{c}}$ Wadia Institute of Himalayan Geology, Dehra Dun 248001, India \\ ${ }^{\mathrm{d}}$ Research School of Earth Sciences, Australian National University, ACT 0200, Australia \\ ${ }^{\mathrm{e}}$ School of Earth Sciences, Macquarie University, Sydney, NSW 2109 Australia
}

Received 12 April 2006; received in revised form 19 January 2007; accepted 26 January 2007

Available online 1 June 2007

\begin{abstract}
The Himalaya-Gangetic Plain region is the iconic example of the debate about the impact on lowlands of upland land-use change. Some of the scientific aspects of this debate are revisited by using new techniques to examine the role of deforestation in erosion and river sediment transport. The approach is whole-of-catchment, combining a history of deforestation with a history of sediment sources from well before deforestation. It is shown that deforestation had some effect on one very large erosional event in 1970, in the Alaknanda subcatchment of the Upper Ganga catchment, but that both deforestation and its effects on erosion and sediment transport are far from uniform in the Himalaya. Large magnitude erosional events occur for purely natural reasons. The impact on the Gangetic Plain of erosion caused by natural events and land cover change remains uncertain.
\end{abstract}

(C) 2007 Published by Elsevier Ltd.

Keywords: Erosion; Sedimentation; Deforestation; Himalaya

\section{Introduction}

In a short paper, following other claims (see Ives and Messerli, 1989, for discussion), Eckholm (1975) posited an environmental crisis in the Himalaya. Among other claims, deforestation of the mountains was blamed for increasing flooding of the Gangetic Plain in India and Bangladesh. Detailed criticism of the postulated crisis, which became known as the theory of Himalayan degradation (THED), followed (e.g. Ives and Messerli, 1989; Ives, 2004). THED became embedded in public policy in Nepal, India and China, so that the early highly speculative papers had a disproportionately large impact (Blaikie and Muldavin, 2004).

THED has also become an iconic example of an environmental myth. Thompson et al. (2006) argued that

\footnotetext{
${ }^{*}$ Corresponding author. Tel.: + 61289466868 .

E-mail address: robert.wasson@cdu.edu.au (R.J. Wasson).
}

the scale of scientific uncertainty was so large that nothing sensible could be gleaned for public policy from existing research. They argued further, in a post-modern flourish, that nothing of value could ever be known about the complex of interacting natural and human forces in the Himalaya. Stott and Sullivan (2000) saw the work of Thompson et al. (2006) as an example of a crucial aspect of political ecology, namely the re-framing of 'accepted environmental narratives, particularly those directed via international environment and development discourses to resource users in the South'.

This quote makes evident the political underpinnings of grand environmental narratives, at least in the view of these and other political ecologists. The need to make these underpinnings clear makes the research landscape very complex. Stott and Sullivan (2000) saw creative research to deal with this complexity as transcending the divide between natural and social sciences; engaging with a range of methods; using complementary sources of data to build 
a rich picture of land-use and environmental ideas, including local narratives; using theoretical frameworks to constrain environmental narratives; understanding the cultural basis of the separation of people and nature; understanding that temporal and spatial scales of observation influence findings; and recognising the importance of history and contingency in the construction of narratives and in the way that environments and technology are managed.

The analysis by Stott and Sullivan (2000) pays insufficient attention to the application of new and evolving techniques from the natural sciences. We contend that much of the scientific input to THED was weak, largely because it failed to take adequate account of temporal and spatial scale. This view was earlier expressed by Ives and Messerli (1989).

In this paper, we examine one part of what became known as THED. We use techniques that were not available to scientists whose work was included in THED. We include many aspects of the research agenda of Stott and Sullivan, including temporal and spatial scale, history and contingency, complementary data sources, theoretical frameworks, and local narratives. However, THED in our view is not a hypothesis worthy of further debate. It is illposed and, in many important ways, impossible to test. Even though what follows was considered part of THED, we do not intend by our study to re-enliven the entire hypothesis. However, our study fits into the ongoing upland-lowland debate, a topic considered next.

\section{The debate and the present study}

Debate about the impact on the Gangetic Plain of land cover and land-use changes in the Himalayan mountains has produced two positions (Ives and Messerli, 1989; Ives, 2004; Hofer and Messerli, 2006): (i) deforestation increases runoff and erosion thereby increasing river channel sedimentation leading to flooding in the lowlands caused by both increased river discharge and reduced river channel capacity; and (ii) deforestation has a trivial effect on erosion, and forests minimally affect runoff, therefore flooding is unaltered.

The link between deforestation, erosion and river sedimentation in the Upper Ganga catchment of the Central Himalaya (Fig. 1) is the focus of our study. River sedimentation and the putative link to flooding on the Gangetic Plain (e.g. CIFOR and FAO, 2005) is not examined. We also only examine the Alaknanda River catchment of $13,993 \mathrm{~km}^{2}$, one of two major tributaries of the Ganga in the Himalaya upstream of Haridwar. This was the site of the infamous 1970 Alaknanda flood and sediment transport event, which the local people blamed on deforestation. The flood was also one of the triggers for the internationally acclaimed Chipko movement (Bahuguna, 1987).

The spatial framework for the study is based on geologic/geomorphic zones in the catchment. From north to south, the Alaknanda/Ganga traverses the Tethyan Sedimentary Series (TSS) on the margin of the Tibetan Plateau, the higher crystalline Himalaya $(\mathrm{HCH})$ where several peaks almost reaching $8000 \mathrm{~m}$ are separated by deep valleys, the Lesser Himalaya (LH), where lower peaks occur, and the Siwaliks (LS) which consist of low hills at the boundary between the LH and the Gangetic Plain (Ahmad et al., 2000). TSS is mostly above the tree-line, $\mathrm{HCH}$ is at or below the tree-line, and LH and LS are below the tree-line.

Using this spatial framework, the study has the following components:

- Evaluation of the existing records of deforestation.

- Determination of the most significant sources of river sediment over the last 6000 years (6 ka hereafter) using

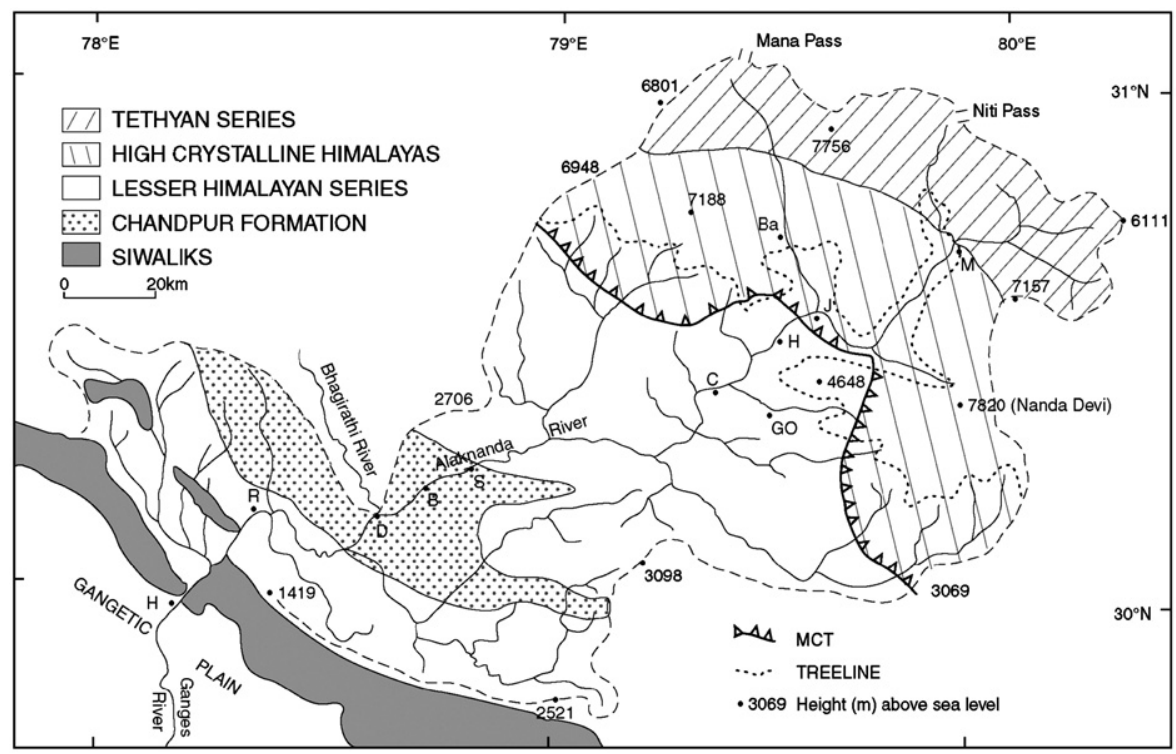

Fig. 1. Location map. H-Haridwar, R-Rishikesh, D-Devprayag. S-Srinagar, Go-Ghona Tal, B-Badrinath, M-Malari, C-Chamoli. 
geochemical tracers and optically stimulated luminescence (OSL) dating.

- Estimation of the volume of the 1970 deposit in a storage zone by comparison with earlier deposits from different sources.

- Examination of the links between deforestation and erosion sources through time.

- Exploration of the vulnerability to erosion of the main source of the 1970 deposit.

\section{Deforestation}

The first written record of the forests of this catchment is from $1624 \mathrm{AD}$, suggesting vast forest cover in the $\mathrm{LH}$ and LS (Wessles, 1924). By the 1920s 'immense tracts' of forest still existed in the LH (Dudgeon and Kenoyer, 1925), but the descriptions also suggest less forest than in 1624. While the qualitative trend of deforestation is clear (Negi et al., 1997), quantification using the same definitions and methods for exactly the same areas is difficult. In 1922, about $25 \%$ of British Garhwal was forested (Singh et al., 1984), and in 2001 about $45 \%$ of the original area of forest of the state of Uttaranchal (which includes the former British Garhwal) was forested (Forest Survey of India, 2001). Official records of the District of Chamoli (mostly $\mathrm{HCH}$ and some $\mathrm{LH}$ ) indicate $57 \%$ forest cover in 1970 and $32 \%$ in 2001 (Zurick and Karan, 1999). The District of Garhwal (all LH) had 84\% forest cover in 1970 and 59\% in 2001(Zurick and Karan, 1999; Forest Survey of India, 2001). Importantly, in 1990 the cropped area was $8 \%$ in Chamoli District and 28\% in Garhwal District (Zurick and Karan, 1999). These values were $9 \%$ and $32 \%$ in 1970 , respectively, showing that agriculture was not the cause of deforestation.

Between 1803 and $1815 \mathrm{AD}$, large numbers of trees were cut during Gorkha rule in the Central Himalaya, but it was mainly during the nineteenth century that Deodar and Chir pines were commercially exploited (Tucker, 1982). Road construction in the catchment after 1962 facilitated commercial logging (Tucker, 1982) that reduced forest cover in Chamoli and Garhwal Districts (Zurick and Karan, 1999). Thus, accelerated forest loss occurred from 1803 onwards, particularly since 1962 . For discussion of the politics and further explanation of land cover change, see, for example, Rangan (1995) and Saberwal (1999).

The accuracy of the quantitative forest cover data is debateable. Definitions of forest, classification of satellite images, protocols for estimating forest cover from aerial photos are all open to question. Fortunately, these issues are not highly important in this study, as accurate data do exist for the area of particular importance, as will be shown.

\section{Sources of sediment}

Being places of high relief, glaciation and landslides, $\mathrm{HCH}$ and TSS are likely major sources of sediments in the Alaknanda River. TSS and $\mathrm{HCH}$ are mostly above the tree line and if they do supply most sediment then deforestation can be discounted as a factor in rates of erosion in the catchment. To test this proposition, the proportion of river sediment derived from $\mathrm{HCH}$ and TSS was estimated.

The geologic/geomorphic zones have different values of the rare earth tracer $€ \mathrm{Nd}(0)$ (Ahmad et al., 2000; McCulloch and Wasserburg, 1978; Robinson et al., 2001). $€ \mathrm{Nd}(0)$ tracer values are the result of a physical mixture of grains from different sources. No chemical partitioning or chemical fractionation occurs. Previously measured values of $€ \mathrm{Nd}(0)$ in modern river samples (Vance et al., 2003) were combined with the data for the present study, determined by methods reported previously (Wasson et al., 2002).

The geologic/geomorphic zones now need a little more elaboration. Within the $\mathrm{LH}$ is an area of $\mathrm{HCH}$ rocks known as the Chandpur Formation (Ahmad et al., 2000). The LH upstream of this Formation is called here Inner Lesser Himalaya (ILH), the Chandpur Formation is $\mathrm{OLH}(\mathrm{C})$, and the LH downstream of the Formation is OLH $(\mathrm{K})$, where $\mathrm{K}$ refers to the Krol Formation.

The input to modern river sediments from each geologic/ geomorphic source zone (TSS, HCH, LH, LS) was calculated as follows. A linear two-end-member mixing model was used when either only two end members (TSS and $\mathrm{HCH}$ ) exist or can be reasonably assumed (ILH and $\mathrm{HCH}$ because the TSS signal completely disappears in the $\mathrm{HCH}$ zone). Further downstream where for example a sample is a mixture of $\mathrm{HCH}$, ILH and OLH (C), the ratio $\mathrm{HCH} / \mathrm{ILH}$ immediately upstream of OLH (C) was taken as one end member and the $€ \mathrm{Nd}(0)$ value for $\mathrm{OLH}$ (C) was the other end member. This procedure assumes that the ratio $\mathrm{HCH} / \mathrm{ILH}$ in the sediments that are receiving input from OLH (C) is maintained, but the percentages of $\mathrm{HCH}$ and ILH in the sample are reduced by the amount of OLH (C) input. The assumption of a constant ratio is plausible because the wide range of lithologies in each sample indicates that the bulk density of the sediments does not vary along the river and so differential transport of sediment of the same particle size from different sources does not occur.

The data show that sediment derived from TSS is rapidly overwhelmed by $\mathrm{HCH}$ material downstream of Malari (Fig. 2). As the river enters the ILH, $€ \mathrm{Nd}(0)$ values decline to a minimum within about $30 \mathrm{~km}$ showing that, near the Main Central Thrust (the MCT, which separates the ILH and $\mathrm{HCH}$ ), the ILH contributes substantial quantities of sediment. The $\mathrm{OLH}(\mathrm{C})$ also contributes sediment to the river, as shown by less negative values. There is a small change in $€ \mathrm{Nd}(0)$ in the $\mathrm{OLH}(\mathrm{K})$ zone, but none is detectable in the upstream part of LS.

The results (Table 1) show that at Rishikesh, at the downstream end of the catchment, about $54 \%$ of the modern river sediment comes from the $\mathrm{HCH}$ and the remainder from the ILH. The OLH $(\mathrm{K})$ and LS contribute negligibly. It is noteworthy that the average $€ \mathrm{Nd}(0)$ at Rishikesh is $-17.3 \pm 0.22$, which is consistent with $100 \%$ derivation from the $\mathrm{HCH}$. Similar results from the Ganga in the lowlands have been used to conclude that about $80 \%$ of the river 


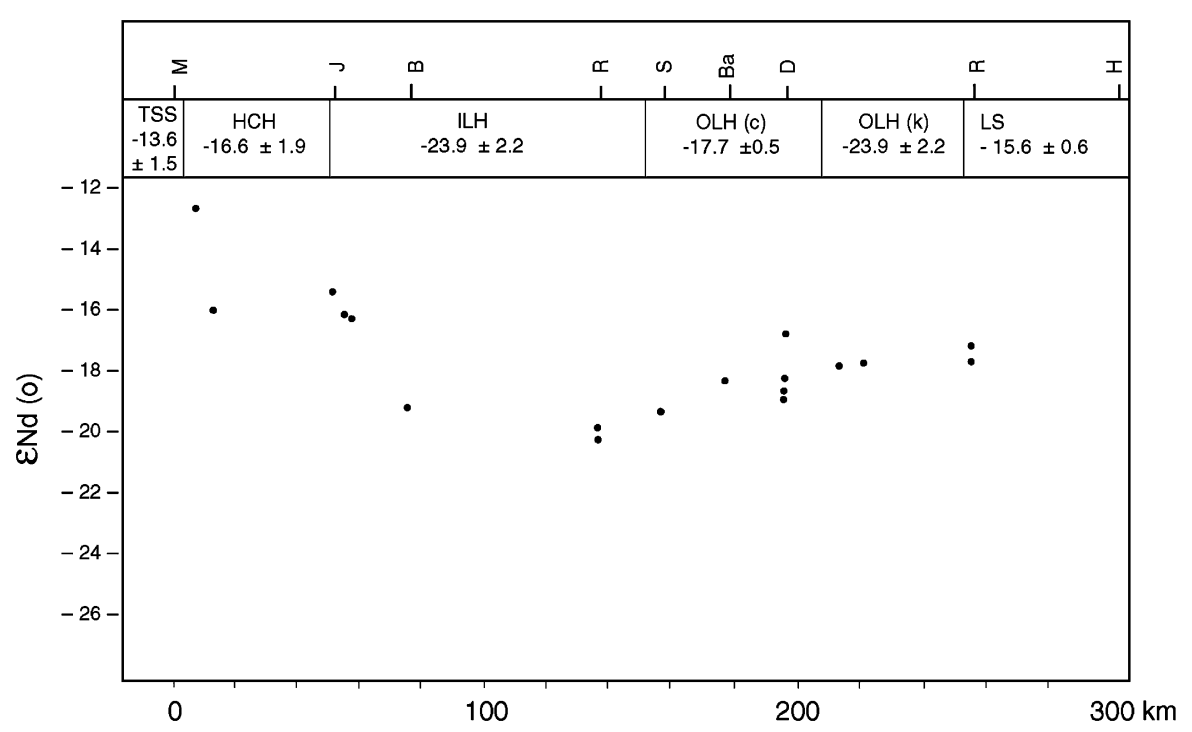

Fig. 2. $€ \mathrm{Nd}(0)$ variation along the Alaknanda River through the geologic/geomorphic zones. The mean $€ N d(0)$ value for each zone is shown. $\mathrm{M}-\mathrm{Malari}$, J-Joshimath, B - Birehi Ganga/Alaknanda junction, R - Rudraprayag, S-Srinagar, Ba-Bagwan, D-Devprayag, R-Rishikesh, H-Haridwar.

Table 1

$€ \mathrm{Nd}(0)$ results and source estimates from Malari to Rishikesh

\begin{tabular}{|c|c|c|c|c|c|c|c|c|}
\hline \multirow[t]{2}{*}{ Location } & \multirow{2}{*}{$\begin{array}{l}\text { Distance from } \\
\text { Malari }(\mathrm{km})\end{array}$} & \multirow[t]{2}{*}{$€ \mathrm{Nd}(\mathrm{O})$} & \multicolumn{6}{|c|}{ Percentage from } \\
\hline & & & TSS & $\mathrm{HCH}$ & ILH & OLH (C) & OLH $(\mathrm{K})$ & LS \\
\hline & 13 & $-16.0^{+}$ & 9 & 91 & & & & \\
\hline Joshimath & 50 & $-15.5^{+}$ & & 100 & & & & \\
\hline Helang & 55 & $-16.1^{+}$ & & 100 & & & & \\
\hline \multirow[t]{2}{*}{ Rudraprayag } & 136 & $-20.1^{+}$ & & 52 & 48 & & & \\
\hline & 136 & $-19.8^{+}$ & & 56 & 44 & & & \\
\hline Srinagar & 156 & -19.2 & & 63 & 36 & 1 & & \\
\hline Bagwan & 176 & $-18.2^{+}$ & & 60 & 34 & 6 & & \\
\hline Devprayag & 195 & $18.7 \pm 1.0^{*+}$ & & 59 & 33 & 8 & & \\
\hline Lower & 212 & $-17.7^{+}$ & & 54 & 30 & 16 & ND & ND \\
\hline
\end{tabular}

$* x \pm 1 \sigma ; n=5$. Uncertainties for single $€ \mathrm{Nd}(\mathrm{O})$ values are $<1.5 \% .{ }^{+}$Data from Vance et al. (2003). ND—not detectable.

sediment is derived from the HCH (France-Lanord et al., 2000). The pattern of variation of $€ \mathrm{Nd}(0)$ along the Alaknanda (Fig. 2, Table 1), however, does not support such an interpretation.

The discussion of sediment sources has thus far focussed on spatial sources. The alarmist paper by Eckholm (1975) stressed loss of topsoil, presumably by sheet and rill erosion. This loss was seen as a disaster for both the agricultural society of the mountains and the plains people who had to endure flooding supposedly caused in part by river channel shallowing as a result of topsoil deposition.

The topsoil tracer ${ }^{210} \mathrm{~Pb}$ (excess) (Wasson et al., 1987) in samples from the Ganga River at Rishikesh and the Birehi Ganga was measured to obtain at least a qualitative indication of the amount of topsoil in the rivers. Low activities of $31 \pm 6 \mathrm{mBq} / \mathrm{g}$ at Rishikesh and $47 \pm 7 \mathrm{mBq} / \mathrm{g}$ in the Birehi Ganga suggest that, while some topsoil reaches the main rivers, it is minimal compared to the erosional processes that move subsoil; namely, landsliding, gullying, and channel erosion. Quantification of the topsoil component of river sediments in this catchment must await further work.

\section{History of erosion and sediment sources}

$€ \mathrm{Nd}(0)$ of modern sediment may represent only a few years of transport from its source(s). Erosion rates based on ${ }^{10} \mathrm{Be}$ and ${ }^{26} \mathrm{Al}$ provide an average value over $200-1000$ years, 
as follows: TSS $1.2 \pm 0.1 \mathrm{~mm} / \mathrm{a}$; $\mathrm{HCH} 2.7 \pm 0.3 \mathrm{~mm} / \mathrm{a}$; and LH $0.8 \pm 0.3 \mathrm{~mm} / \mathrm{a}$ (Vance et al., 2003). Modern suspended sediment loads for the Alaknanda below Helang (at the MCT) were derived by regressing measured loads (data tabulated by Kale and Gupta, 2001) on catchment area at each station, and then loads from each source terrain were calculated using the regression equation. The ratio of loads from the $\mathrm{HCH}$ and $\mathrm{LH}$ is 2.1 for the long term and 1.8 for the modern suspended load. The ratios are 1.5 and 1.1 for the ILH and OLH, respectively. Even though the loads for the long-term are higher than the modern rates, because bedload is included in the former, the change of ratios between the long term and today suggests that the LH and OLH are now a more significant source.

For a time-specific history of sediment sources, and their relationship to two centuries of deforestation, a stratigraphic sequence from the alluvial deposits of the Alaknanda River at Srinagar was examined (Figs. 1 and 3). This wide part of the valley is immediately upstream from a narrow gorge, and acts as a sediment trap. The sampling site is close to the downstream margin of the ILH. It was assumed that TSS was an unimportant source at Srinagar, being swamped by $\mathrm{HCH}$ (Table 1). Therefore, only HCH and LH sources were considered. Each deposit was optically dated using bluegreen stimulated luminescence of $90-150 \mu \mathrm{m}$ quartz grain separates. The single aliquot regeneration method and the minimum $10 \%$ palaeodose were used to calculate the ages (Aitken, 1998). Dose rate was estimated using thick source $\mathrm{ZnS}(\mathrm{Ag})$ alpha counting and $\mathrm{NaI}(\mathrm{Tl})$ gamma spectrometry.

The oldest sediment at $6.3 \pm 0.7 \mathrm{ka}$ is from a braid deposit on the left bank (Table 2). Between $2.7 \pm 0.7$ and $0.8 \pm 0.1 \mathrm{ka}$ a lateral accretion deposit accumulated, topped by boulders forming part of a building. A silty clay overbank deposit accumulated at $400 \pm 40$ a on top of the boulders, the surface of which is occupied by the Keshav Rai temple built in 1624/25 AD (Negi, 1988). Covering this layer is $\sim 3 \mathrm{~m}$ of sediment unambiguously assigned by the local people to the 1970 flood. On the right bank, basal deposits in a large lateral bar were deposited in flood couplets at about $230 \pm 60$ a, and are overlain by the 1970 deposit.

The $€ \mathrm{Nd}(0)$ results from these deposits (Table 2) show that the sediments at 6.3 and $2.7 \mathrm{ka}$ were mainly derived from the $\mathrm{HCH}$, probably as a result of enhanced monsoon rainfall that penetrated further north than at present (Bookhagen et al., 2005). The $0.8 \mathrm{ka}$ sediment was approximately equally derived from the ILH and $\mathrm{HCH}$. The 400 a and 230 a flood deposits were mostly from the HCH. The 1970 deposit had the highest contribution from the ILH, and modern sediment is mostly from the $\mathrm{HCH}$.

It appears that only a small proportion of modern sediment in the Ganga and Birehi Ganga comes from topsoil, but we currently have no technique for estimating this proportion for sediments older than about 100 years.

Table 2

OSL dates and source estimates for alluvial deposits at Srinagar

\begin{tabular}{llll}
\hline Age of deposit & Sediment type & HCH (\%) & ILH (\%) \\
\hline Modern & River channel & 64 & 36 \\
$1970 \mathrm{AD}$ & Overbank & 45 & 55 \\
$230 \pm 60 \mathrm{a}$ & Flood couplets & 67 & 33 \\
$400 \pm 40 \mathrm{a}$ & Overbank & 86 & 14 \\
$800 \pm 100 \mathrm{a}$ & Laterally accreted fluvial sand & 52 & 48 \\
$2700 \pm 700 \mathrm{a}$ & & 86 & 14 \\
$6300 \pm 800 \mathrm{a}$ & Braid bar & 78 & 22 \\
\hline
\end{tabular}

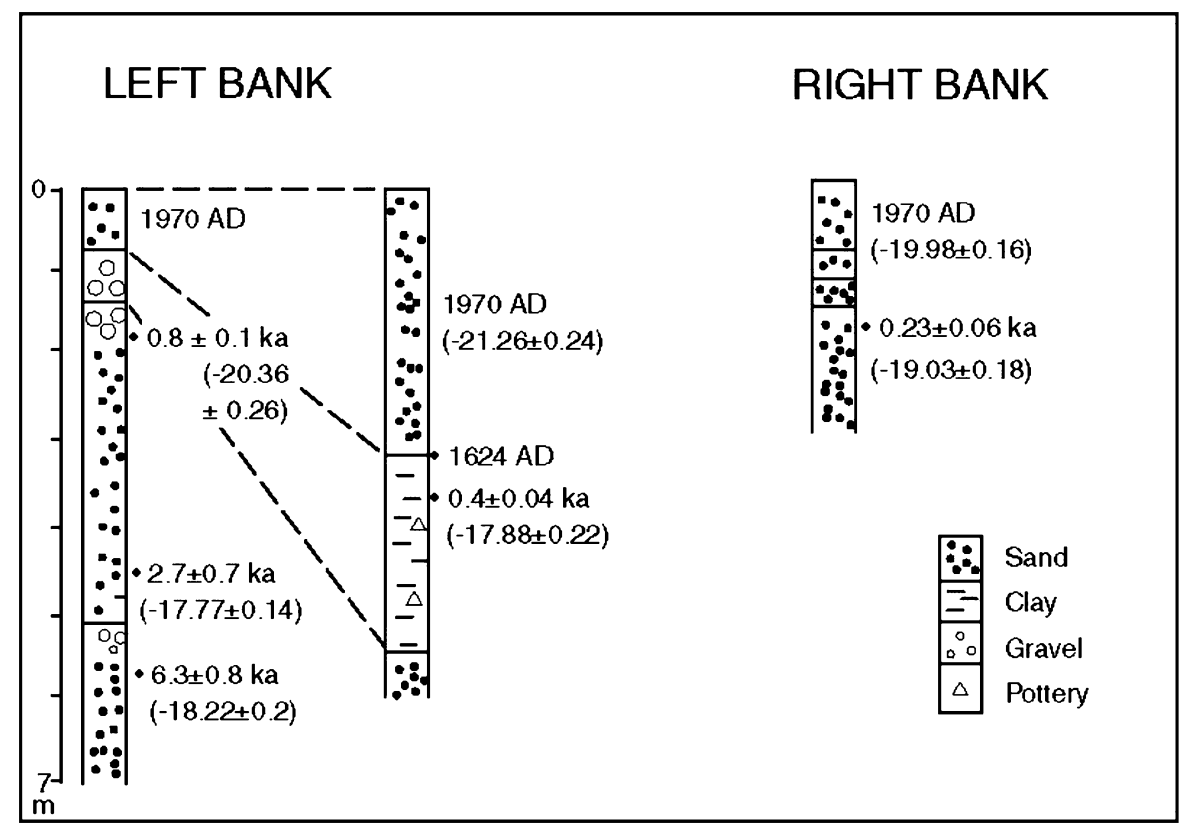

Fig. 3. Stratigraphic columns for alluvial deposits of Srinagar. OSL dates and $€ \mathrm{Nd}(0)$ values are shown. 


\section{The 1970 event}

These results show that, at this site, during the last $6.3 \mathrm{ka}$, the highest proportion of ILH sediment in any of the deposits is in the sediments of the 1970 flood; although there is little difference between the $0.8 \mathrm{ka}$ and 1970 deposits. Major deforestation occurred just before 1970, in the ILH source area of this deposit, and the 1970 deposit in this part of the valley constitutes $\sim 30 \%$ of the total accumulation during the last $6.3 \mathrm{ka}$. The $0.8 \mathrm{ka}$ deposit is of uncertain volume because it is the top of a deposit only dated by two analyses, but it certainly seems to be of much smaller volume than that of 1970 .

Field survey of the 1970 deposit makes it clear that most of it originated in the Birehi Ganga catchment, where the flood sediment is up to $14 \mathrm{~m}$ thick. The deposit begins near the upstream end of Ghona Tal (lake) (Fig. 1) where the right bank tributary Pui Gadhera reaches the valley floor (Kimothi and Juyal, 1996). At this point, the deposit comprises $100 \%$ LH (Table 3) showing that the intense rain at the time had minimal effect on the $\mathrm{HCH}$ upstream of Ghona Tal in the Birehi Ganga Valley. Deposits $15 \mathrm{~km}$ downstream in the Birehi Ganga are also $100 \%$ LH. At Srinagar the deposit comprises between $36 \%$ and $54 \%$ $\mathrm{HCH}$, and at Bagwan, $100 \mathrm{~km}$ downstream from the Birehi Ganga on the Alaknanda River, the deposit comprises 50 and $73 \% \mathrm{HCH}$. At Bagwan, on the right bank, three benches of 1970 deposit were probably formed by surges of sediment of decreasing magnitude. The lowest (youngest) surge includes $73 \% \mathrm{HCH}$ material, while the middle surge has only $50 \% \mathrm{HCH}$ content. These results show that, although the calcareous rocks of the LH near the MCT were a major source, $\mathrm{HCH}$ material was also entrained both from areas upstream of the MCT (probably from landslides near Tapovan) and reworking of pre-1970 flood sediment along the Alaknanda valley.

The 1970 flood and sediment transport event in the Birehi Ganga valley were preconditioned by a huge landslide near the village of Ghona in 1893. Ghona Tal, the lake formed by the landslide, had a volume of about $408 \times 10^{6} \mathrm{~m}^{3}$ and the landslide debris was between 150 and $200 \times 10^{6} \mathrm{~m}^{3}$ in volume (Nand and Prasad, 1972; Weidinger, 1998; Glass, 1896). The dam breached in 1894 sending sediment as far downstream as Haridwar. The bed of the

Table 3

$€ \mathrm{Nd}(0)$ data and source estimates for the 1970 deposit

\begin{tabular}{llll}
\hline & $€ N d(\mathrm{O})$ & LH $(\%)$ & HCH $(\%)$ \\
\hline Ghona Tal & $-22.12 \pm 0.22$ & 100 & \\
Birehi Ganga & $-21.65 \pm 0.12$ & 100 & \\
Srinagar & $-21.52 \pm 0.16$ & 100 & \\
Bagwan & $-21.07 \pm 0.13$ & 100 & 54 \\
& $-19.98 \pm 0.16$ & 46 & 36 \\
& $-21.26 \pm 0.24$ & 64 & 50 \\
& $-20.18 \pm 0.20$ & 50 & 73 \\
\hline
\end{tabular}

Birehi Ganga just downstream of Ghona was raised $\sim 70 \mathrm{~m}$ by deposition, and at Chamoli the Alaknanda river bed was raised by $\sim 15 \mathrm{~m}$. The landslide debris, and the alluvium derived from the breach of 1894 , provided a readily erodible source of sediment for future floods.

In 1924, a landslide upstream of Ghona Tal displaced water from the lake which then eroded more of the landslide debris and downstream alluvium (Gupta, 1974). The runoff of 1970 breached the landslide dam again and emptied the lake. Part of the dam was mobilised along with the downstream alluvium deposited in 1894 and probably 1924. Landslides in the Patal Ganga and Garud Ganga catchments also formed lakes that burst within hours of their formation, adding sediment to that from the Birehi Ganga to be transported down the Alaknanda River (Nand and Prasad, 1972). Sediment once again reached Haridwar where the Upper Ganga Canal was filled over a stretch of $11 \mathrm{~km}$.

Without the natural landslide of 1893, there would have been less water and sediment available in 1970. The role of history and contingency in the analysis of the event is therefore crucial.

We now examine the role of deforestation in the landslides of 1970. In the Birehi Ganga, Patal Ganga and Garud Ganga catchments, Forest Department records enabled identification of compartments that were clearfelled between 1959 and 1969. These were identified on 1972 Landsat images and landslide scars were mapped (Kimothi and Juyal, 1996). About 70\% of the deforested compartments were sites of landslides in 1970, and the remainder of the landslides occurred in forest and alpine pasture. The main area of landslides in the Patal Ganga catchment occurred where hillslopes with an average angle of $25^{\circ}$ had been deforested. Although the volumes of the landslides were not measured after the 1970 event, they were almost all shallow (see Barnard et al., 2001). Therefore, an estimate of the area of landslides that occurred in deforested compartments is probably a reasonable approximation to the volume affected by deforestation.

The event of 1970, and also that of 1894,deposited sediment on the Gangetic Plain near Haridwar, and caused local flooding (Nand and Prasad, 1972). The sedimentary structures in the 1970 deposits show that the valley floor was braided over extensive reaches. Once the mainly landslide debris was exhausted, and the flood was over, the deposits were incised by subsequent smaller flows. Sediment from this event can be seen in the floodplain a little downstream of Haridwar. Whether or not this sediment shallowed the Ganga channel, or contributed only to floodplain deposits, is not known.

\section{Vulnerability to erosion of the source area of the $\mathbf{1 9 7 0}$ event}

Most of the sediment carried downstream in 1970 came from within $30 \mathrm{~km}$ of the MCT (Kimothi and Juyal, 1996), an area already identified as producing a large amount of 


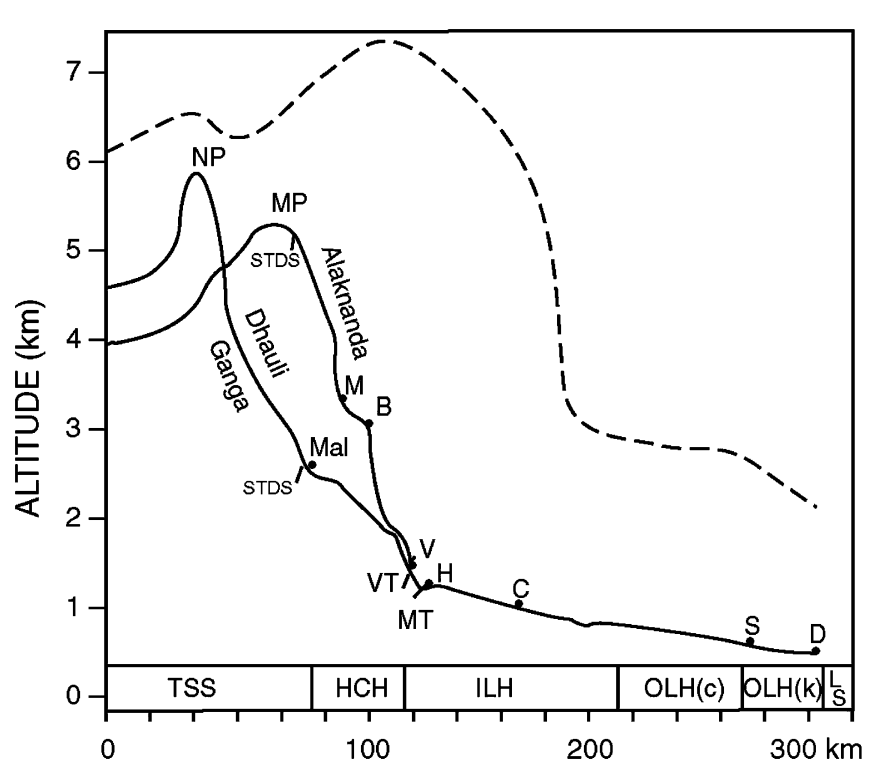

Fig. 4. Longitudinal profiles of the Alaknanda between Devprayag and Mana Pass, and of the Dhauli Ganga between Vishnuprayag and Niti Pass. Also shown is the envelope of greatest altitude (dashed line) and the geologic/geomorphic zones. D-Devprayag, S-Srinagar, C-Chamoli, H-Helang, V-Vishnuprayag, Mal-Malari, B-Badrinath. M-Mana, MP_Mana Pass, NP_Niti Pass, TT-Tons Thrust, MT-Munsiari Thrust, VT - Vaikrita Thrust, STDS — South Tibetan Detachment system.

the modern river sediment (Fig. 2). This area is particularly sensitive to disturbance. Fig. 4 shows a longitudinal profile of the Alaknanda River based on both a 1:150,000 map by the Schweizerischen Stiftung für Alpine Forschungen (2002) and Pal (1986). Upstream of Vishnuprayag, longitudinal profiles of both the Alaknanda and Dhauli Ganga are provided along with the envelope of maximum elevations. The longitudinal profiles are steep above the MCT zone, which in this region is defined by the Munsiari and Vaikrita Thrusts. Also of note is the convexity of the Dhauli Ganga between Malari (at the southern Tibetan Detachment System, that separates the TSS from the $\mathrm{HCH}$ ) and Vishnuprayag. A less prominent convexity is also evident in the Alaknanda longitudinal profile.

The convexity is explained as the result of uplift (possibly by extrusion) of the $\mathrm{HCH}$ at a rate faster than fluvial downcutting (Beaumont et al., 2001). In this zone of fastest uplift in the Central Himalaya (Jackson and Bilham, 1994), modelling and estimates of rates of erosion given by fission track cooling ages in rocks of the HCH (Sorkhabi et al., 1996) indicate an erosion rate of $\sim 2 \mathrm{~mm} /$ year averaged over the past 2.4 million years. This implies that fluvial incision is $<2 \mathrm{~mm} /$ year in the convex zone. Erosion is also focussed in this part of the Himalaya (the Southern Himalayan Front, SHF) by high orographic rainfall (Hodges et al., 2004), and stream power is at a maximum, particularly in the Alaknanda Valley (Finlayson et al., 2002).

High stream gradients and stream power imply both rapid steam incision and rapid evacuation of sediments, and creation of steep hillslopes, adjacent to rivers, that erode quickly. Mean hillslope angle, mean relief and erosion rate are all highly correlated in the Himalaya (Montgomery and Brandon, 2002; Gabet et al., 2004). The greatest relief in the Alaknanda Valley is $5.5-6.0 \mathrm{~km}$ between Helang and Chamoli (Fig. 4) where average hillslope angles adjacent to the river are about $30^{\circ}$. Further downstream average hillslope angles range between $20^{\circ}$ and $13^{\circ}$, where maximum relief falls to between 1500 and $2000 \mathrm{~m}$ (Pal, 1986).

\section{Discussion}

Deforestation increased during the last 200 years and, particularly since 1962 in the LH. Sediment currently being transported by the Ganga River at the mountain front is derived in approximately equal amounts from the $\mathrm{HCH}$ and $\mathrm{LH}$. It is therefore clear that the high relief $\mathrm{HCH}$ does not dominate modern sediment sources. Also, nearly $70 \%$ of the LH sediment comes from within $30 \mathrm{~km}$ of the MCT. A small but as yet unquantified proportion of modern river sediments is derived by erosion of topsoil.

In the last $6.3 \mathrm{ka}$, the largest contribution from the $\mathrm{LH}$ to sediment deposited at Srinagar occurred in 1970, and this deposit constitutes $\sim 30 \%$ of the total sediment deposited in this section of the valley during the past $6.3 \mathrm{ka}$. Almost the same proportion of LH material occurred in the $0.8 \mathrm{ka}$ deposit, well before deforestation. The cause of this erosion of the LH was natural, related to rainfall and/or an earthquake. Most of the sediment transported during the 1970 Alaknanda Flood came from the same area as the modern sediment, that is, the SHF both a little upstream of the MCT and within $30 \mathrm{~km}$ downstream of the MCT. The SHF is the area of highest total and mean relief, steepest hill slopes, fractured and sheared rocks, fastest uplift, and high rainfall. Hill slope gradients are maintained at or near the threshold for shallow landsliding (and sometimes deep landsliding) by rapid fluvial downcutting. During the prolonged and at times intense rainfall of 1970, about $70 \%$ of the landslides occurred on deforested hillslopes, adding substantially to deposition downstream. Some of the sediment also came from the breach of Ghona Tal.

The role of land cover in landslide location and magnitude identified in the Alaknanda Valley is consistent with some quantitative studies elsewhere in the Himalaya (Starkel and Basu, 2000; Valdiya and Bartarya, 1989). By contrast, erosion and sediment transport that dramatically reduced the capacity of a reservoir and thereby Nepal's main source of hydro-electricity in the Kulekhani catchment was caused by landslides that occurred in grassland and forest areas (Dhital et al., 1993). Also, Gardner (2002) showed that in the Kullu District of Himachal Pradesh, little deforestation has occurred but landslides and debris flows are a common occurrence. Road construction has, however, caused landslides.

Deforestation does have an effect, but it occurs in concert with undercutting of slopes by road construction, zones of sheared rock, and saturating rainfall that can 
trigger landslides even in well-forested land on steep slopes and that precondition the landscape to produce even more sediment transport during later periods.

The central Himalaya is a very complex landscape, prone to very high rates of erosion and sediment transport often produced under extreme conditions. The role of land-use, particularly deforestation, in this landscape is difficult to discern. Only the 1970 event can be partly explained by deforestation, with a significant role played by pre-existing (or contingent) events; namely, the creation and breach of Ghona Tal.

The extreme vulnerability of the SHF indicates that erosion here will always be high whatever the land-use. But under some circumstances deforestation will cause increased erosion. It follows that reforestation will help to moderate the effects of some extreme rainfall events, but cannot be expected to stop erosion and destructive sediment transport. The effects on local people of reforestation of course need careful consideration (Sinha, 2001).

The impact of human-induced erosion in the Himalaya on channel sedimentation in the Gangetic Plain has not been investigated in our study. Construction of histories of both channel and floodplain sedimentation will be necessary, and estimates made of the travel times of sediment in the main rivers (cf. Schreier and Wymann von Dach, 1996) so that correlations between land cover changes and erosion in the mountains with sedimentation on the plains are meaningful.

Finally, if current ideas about paying upland land users for environmental services provided to lowlanders (Wunder, 2005) are put into practice, the role of land cover will need to be quantified. Otherwise, payments will be stalled in uncertainty, argument and possibly litigation.

\section{Conclusion}

Identifying the role of human agency in the erosion and sediment transport system of the Himalaya is difficult. Nonetheless, by using geochemical sediment source tracers and a historical approach set within a whole-of-catchment framework, it has been possible to show that deforestation had some impact on at last one very large erosion and sediment transport event. The temporal and spatial framework adopted is different from that previously used, and historical contingency has been explicitly analysed. We have drawn upon many data sources including local narratives. By a careful step-by-step approach, the upland-lowland debate in the Himalaya-Gangetic Plain can be sensibly re-examined, and public policy appropriately informed.

\section{Acknowledgements}

We thank Bruno Messerli for stimulating debate, the people of Garhwal for many kindnesses, Jo Pinter for assistance with the manuscript, and Jack Ives for a review of the paper.

\section{References}

Ahmad, T., Harris, N., Bickle, M., Chapman, H., Bunbury, J., Prince, C., 2000. Isotopic constraints on the structural relationships between the Lesser Himalaya series and the High Himalayan Crystalline Series, Garhwal Himalaya. Geological Society of America Bulletin 112, 467-477.

Aitken, M.J., 1998. An Introduction to Optical Dating. Oxford University Press, Oxford, 280pp.

Bahuguna, S., 1987. The Chipko: a people's movement. In: Raha, M.K. (Ed.), The Himalayan Heritage. Gian, New Delhi, pp. 238-248.

Barnard, P.L., Owen, L.A., Sharma, M.C., Finkel, R.C., 2001. Natural and human-induced landsliding in the Garhwal Himalaya of northern India. Geomorphology 40, 21-35.

Beaumont, C., Jamieson, R.A., Nguyen, M.H., Lee, B., 2001. Himalayan tectonics explained by estrusion of low-viscosity crustal channel coupled to focused surface denudation. Nature 414, 738-742.

Blaikie, P.M., Muldavin, J.S.S., 2004. Upstream, Downstream, China, India: The politics of environment in the Himalayan Region. Annals of the Association of American Geographers 94, 520-548.

Bookhagen, B., Thiede, R.C., Strecker, M.R., 2005. Late Quaternary intensified monsoon phases control landscape evolution in the northwest Himalaya. Geology 33, 149-152.

CIFOR and FAO, 2005. Forests and Floods. Drowning in fiction or thriving on facts? CIFOR.

Dhital, M.R., Khanal, N., Thapa, K.B., 1993. The role of extreme weather events, mass movements, and land-use changes in increasing natural hazards. Workshop Proceedings: Causes of the Recent Damage Incurred in South-Central Nepal, July 19-21. ICIMOD, 123pp.

Dudgeon, Kenoyer, L.A., 1925. The ecology of Tehri Garhwal: a contribution to the ecology of the western Himalaya. The Journal of Indian Botanical Society 4, 232-284.

Eckholm, E.P., 1975. The deterioration of mountain environments. Science 189, 764-770.

Finlayson, D.P., Montgomery, D.R., Hallet, B., 2002. Spatial coincidence of rapid inferred erosion with young metamorphic massifs in the Himalayas. Geology 30, 219-222.

Forest Survey of India, 2001. The State of Forest Report. Ministry of Environment and Forest, Government of India, New Delhi.

France-Lanord, C.L., Derry, A., Michard, A., 2000. Himalayan tectonics. Geological Society of Special Publication 74, 603.

Gabet, E.J., Pratt-Sitaula, B.A., Burbank, D.W., 2004. Climatic controls on hillslope angle and relief in the Himalayas. Geology 32, 629-632.

Gardner, J.S., 2002. Natural hazard risk in the Kullu District, Himachal Pradesh, India. The Geographical Review 92, 282-306.

Glass, J.H., 1896. The great landslip at Gohna, in Garhwal, and the measures adopted to prevent serious loss of life. Journal of the Society of Arts 27, 431-446.

Gupta, A.C., 1974. Lakes of sorrow. Indian Engineer Journal C1 55, 6-11.

Hodges, K.V., Wobus, C., Ruhl, K., Schlidgen, T., Whipple, K., 2004. Quaternary deformation, river steepening, and heavy precipitation at the front of the Higher Himalayan ranges. Earth and Planetary Science Letters 220, 379-389.

Hofer, T., Messerli, B., 2006. Floods in Bangladesh, History, Dynamics and Rethinking the Role of the Himalayas. United Nations University Press, Tokyo, 468pp.

Ives, J.D., 2004. Himalayan Perceptions. Routledge, London, 271pp.

Ives, J.D., Messerli, B., 1989. The Himalayan Dilemma. Routledge, London, 295pp.

Jackson, M., Bilham, R., 1994. Constraints on Himalayan deformation inferred from vertical velocity fields in Nepal and Tibet. Journal of Geophysical Research 99, 13897-13912.

Kale, V.S., Gupta, A., 2001. Introduction to Geormorphology. Orient Longman, Hyderabad, 274pp.

Kimothi, M.M., Juyal, N., 1996. Environmental impact assessment of a few selected watersheds of the Chamoli district (Central Himalaya) using remotely sensed data. International Journal of Remote Sensing 17, 1391-1405. 
McCulloch, M.T., Wasserburg, G.J., 1978. Sm-Nd and Rb-Sr chronology of continental crust formation. Science 200, 1003-1011.

Montgomery, D.R., Brandon, M.T., 2002. Topographic controls in erosion rates in tectonically active mountain ranges. Earth and Planetary Science Letters 201, 481-489.

Nand, C., Prasad, C., 1972. Alaknanda Tragedy. A Geomorphological Appraisal. The National Geographical Journal of India 18, 205-212.

Negi, S., 1988. Madhye Himalaya ke Rajnetik Awana Sanskrit Itihas (Middle Himalaya Political and Cultural History). Wani Prakasha, New Delhi.

Negi, A.K., Bhatt, B.P., Todaria, N.P., Saklani, A., 1997. The effects of colonialism on forests and the local people in the Garhwal Himalaya, India. Mountain Research and Development 17, 159-168.

Pal, S.K., 1986. Geomorphology of River Terraces along Alaknanda Valley, Garhwal Himalaya. B.R. Publishing Group, Delhi, 158pp.

Rangan, H., 1995. Contested boundaries: State policies, forest classifications, and deforestation in the Garhwal Himalayas. Antipode 27L, 343-362.

Robinson, D.M., DeCelles, P.G., Patchett, P.J., Garzione, C.N., 2001. The kinematic evolution of the Nepalese Himalaya interpreted from Nd isotopes. Earth and Planetary Science Letters 192, 507-521.

Saberwal, V., 1999. Pastoral Politics. Oxford University Press, Delhi, $246 \mathrm{pp}$.

Schreier, H., Wymann von Dach, S., 1996. Understanding Himalayan processes: shedding light on the Dilemma. In: Hurni, H., Kienholz, H., Wanner, H., Wiesmann, V. (Eds.), Umwelt Mensch Gebirge. Festschrift for Bruno Messerli. Jahrbuch der Geographischen Gessellschaft Bern, Bd. 59/1994-1996. Berne, Switzerland, pp. 75-83.

Singh, J.S., Pandey, U., Tiwari, A.K., 1984. Man and forests: a Central Himalayan Case Study. Ambio 13, 80-87.

Sinha, B., 2001. Timber ban and its effect on the Himalayan rural women and rural energy. Boiling Point 47, 30-32.

Sorkhabi, R., Stump, E., Foland, K.A., Jain, A.K., 1996. Fission-track and ${ }^{40} \mathrm{Ar} /{ }^{39} \mathrm{Ar}$ evidence for episodic denudation of the Gangotri granites in the Garhwal Higher Himalaya, India, Tectonophysics 260, 187-199.

Starkel, L., Basu, S. (Eds.), 2000. Rains, Landslides and Floods in the Darjiling Himalaya. Indian National Science Academy, New Delhi, 168pp.

Stott, P., Sullivan, S., 2000. Introduction. In: Stott, P., Sullivan, S. (Eds.), Political Ecology. Science, Myth and Power. Arnold, London, pp. 1-11.

Thompson, M., Warburton, M., Hatley, T., 2006. Uncertainty on a Himalayan Scale. 2nd ed. Himal, Kathmandu.

Tucker, R.P., 1982. The forests of the western Himalayas: the legacy of British Colonial Administration. Journal of Forest History 26, 112-124.

Valdiya, K.S., Bartarya, S.K., 1989. Problem of mass-movements in a part of Kumaun Himalaya. Current Science 58, 486-491.

Vance, P., Bickle, M., Ivy-Ochs, S., Kubik, P.W., 2003. Erosion and exhumation in the Himalaya from cosmogenic isotope inventories of river sediments. Earth and Planetary Science Letters 206, 273-288.

Wasson, R.J., Caitcheon, G., Murray, A.S., McCulloch, M., Quade, J., 2002. Sourcing sediment using multiple tracers in the catchment of Lake Argyle, Northwestern Australia. Journal of Environmental Management 29, 634-636.

Wasson, R.J., Clark, R.L., Nanninga, P.M., Waters, J., 1987. Pb-210 as a chronometer and tracer, Burrinjuck Reservoir, Australia. Earth Surface Processes and Landforms 12, 399-414.

Weidinger, J.T., 1998. Case history and hazard analysis of two lakedamming landslides in the Himalayas. Journal Asian Earth Sciences $16,323-331$.

Wessles, C., 1924. Early Jesuit Travellers in Central Asia 1603-1721. Martinus Nijhoff, The Hague.

Wunder. S., 2005. Payments for environmental services: some nuts and bolts. CIFOR Occasional Paper No. 42.

Zurick, D., Karan, P.P., 1999. Himalaya. The Johns Hopkins University Press, Baltimore, MD, 355pp. 